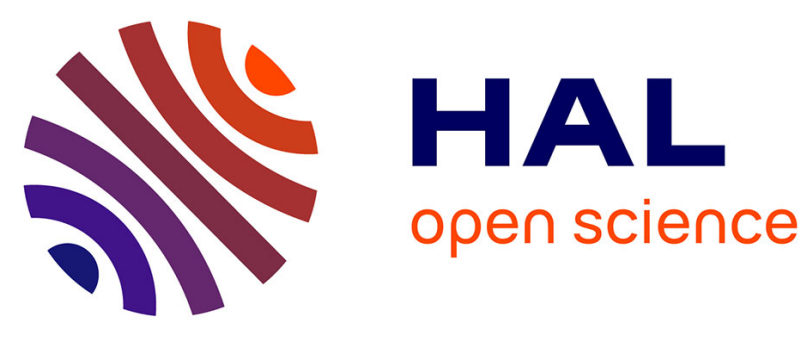

\title{
Enhanced regioselectivity in palladium-catalysed asymmetric methoxycarbonylation of styrene using phosphetanes as chiral ligands
}

Bianca Munoz, Angela Marinetti, Aurora Ruiz, Sergio Castillon, Carmen Claver

\section{To cite this version:}

Bianca Munoz, Angela Marinetti, Aurora Ruiz, Sergio Castillon, Carmen Claver. Enhanced regioselectivity in palladium-catalysed asymmetric methoxycarbonylation of styrene using phosphetanes as chiral ligands. Inorganic Chemistry Communications, 2005, 8 (12), pp.1113-1115. 10.1016/j.inoche.2005.09.006 . hal-00114840v2

\section{HAL Id: hal-00114840 \\ https://hal.science/hal-00114840v2}

Submitted on 20 Nov 2006

HAL is a multi-disciplinary open access archive for the deposit and dissemination of scientific research documents, whether they are published or not. The documents may come from teaching and research institutions in France or abroad, or from public or private research centers.
L'archive ouverte pluridisciplinaire HAL, est destinée au dépôt et à la diffusion de documents scientifiques de niveau recherche, publiés ou non, émanant des établissements d'enseignement et de recherche français ou étrangers, des laboratoires publics ou privés. 


\section{Enhanced regioselectivity in palladium-catalysed asymmetric methoxycarbonylation of styrene using phosphetanes as chiral ligands}

Bianca Muñoz, ${ }^{a}$ Angela Marinetti, ${ }^{b}$ Aurora Ruiz, ${ }^{a}$ Sergio Castillon ${ }^{c}$ and Carmen Claver* ${ }^{a}$

${ }^{a}$ Departament de Química Física i Inorgànica, Universitat Rovira i Virgili, Marcelli Domingo s/n 43007

Tarragona, Spain. Fax: +34 977 559563; Tel: +34 977 559575; E-mail: carmen.claver@urv.net

${ }^{b}$ Institut de Chimie des Substances Naturelles, CNRS, Avenue de la Terrasse, 91198 Gif-sur-Yvette France.

${ }^{c}$ Departament de Quimica Orgànica, Universitat Rovira i Virgili, Marcelli Domingo s/n 43007 Tarragona, Spain.

The palladium-catalysed asymmetric methoxycarbonylation of styrene has been investigated for the first time using phosphetanes as chiral ligands and showed good catalytic activity, excellent regioselectivity to the branched product and enantioselectivity up to $29 \%$.

Over the past two decades, the asymmetric methoxycarbonylation of styrene (equation 1) has been extensively studied as a route to obtain 2arylproprionic acids, the most important class of non-steroidal anti-inflammatory drugs. ${ }^{1}$

Catalysts containing bidentate diphosphine ligands have been frequently used for this reaction, but generally afford low regio- and enantioselectivity to the branched product. ${ }^{2}$ Only a few successful examples have been reported using these catalytic systems ${ }^{3}$. Monodentate phosphines have recently received more attention due to their significant potential in various catalytic processes ${ }^{4}$. In the palladium-catalysed methoxycarbonylation of styrene, their use provides high regioselectivities to the branched ester although the enantioselectivity is usually low. Commetti and Chiusoli ${ }^{5}$ reported the use of neomenthyldiphenyl phosphine A (Fig. 1), Later Nozaki and coworkers ${ }^{6}$ used the phospholane ligand $\mathbf{B}$ and recently the same authors reported on the application of palladium complexes with binaphthol-derived phosphines $\mathbf{C}$ in the methoxycarbonylation of vinylarenes achieving $53 \%$ ee with the branched ester as the only reaction product. ${ }^{7}$ A similar behaviour was observed for related palladium-catalysed hydroxycarbonylations of styrene, where it has been found that palladium complex containing monodentate ligands produce excellent regioselectivity to the branched acids but low enantioselectivity, while systems containing bidentate ligands mainly produce linear acids. ${ }^{8}$ The mechanistic aspects of hydroxycarboxylation and methoxycarbonylation of styrene have recently been reviewed. ${ }^{9}$

Phosphetane ligands have only recently been introduced in homogeneous catalysis. ${ }^{10}$ Their restricted conformational freedom, due to the presence of a four-membered ring, is expected to enhance the chiral induction during the catalytic processes. ${ }^{11}$ These highly hindered, chiral phosphines have been reported in asymmetric hydrogenation reactions catalysed by rhodium and ruthenium complexes. ${ }^{12}$ Phosphetanes based palladium catalyst were also used in processes such as olefin hydrosilation and allylic nucleophilic substitutions. ${ }^{13}$ Here, we report our preliminary results obtained in the asymmetric methoxycarbonylation of styrene catalysed by palladium complexes bearing monodentate chiral phosphetane ligands. This is the first time that such ligands are used in carbonylation reactions.

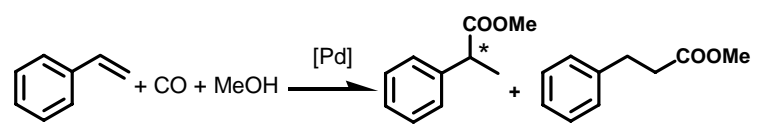

Scheme 1. Pd-catalysed methoxycarbonylation of styrene

A<smiles>CC1CC[C@@H](C(C)C)[C@H](Pc2ccccc2)C1</smiles>

Cometti et al., 1982 ee $=52 \%$
$\mathrm{~b} / \mathrm{l}=94 / 6$
B<smiles>CC1CC[C@@H](C)P1c1ccccc1</smiles>

Nozaki et al., 1997 $\mathrm{ee}=2.4 \%$
$\mathrm{~b} / \mathrm{l}=98 / 2$
C

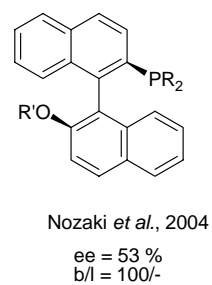

Fig. 1. Monodentate phosphines previously used in asymmetric methoxycarbonylation of styrene. (A)[5], (B) [6], (C) [7]

The syntheses of the phosphetane ligands 1-4 (Fig. 2) and palladium complexes $\mathrm{PdCl}_{2}(3)_{2}$ were performed according to the literature procedures. ${ }^{10,13 a, 13 b, 14}$ The ligands $\mathbf{1 - 4}$ were first tested for catalysis using $\mathrm{PdCl}_{2}$ as palladium precursor, under standard conditions. The results obtained are summarised in Table 1 . When the phosphetane 1 was used, 97\% conversion was obtained with a chemoselectivity to the esters of 99\% and a regioselectivity to the branched product of $98 \%$ (run 1). Moreover, chirality was induced by the ligand $\mathbf{1}$ in this system and yielded an enantiomeric excess of $12 \%$. However, when the bulkier ligands $\mathbf{2}$ and $\mathbf{3}$ were used for this reaction, the conversion was found to decrease considerably, although the 
chemo- and regioselectivity of the reactions remained high (runs 2 and 3). It should be noted that the simple replacement of the two phenyl rings of 2 by methyl groups in $\mathbf{3}$ resulted in a substantial decrease in the activity of the catalyst and in the chemoselectivity of the reaction. The utilisation of the ferrocenylphosphetane $\mathbf{4}$ exhibited an even greater diminution in catalysts activity and chemoselectivity, although the ratio of branched to linear esters remained 99:1. In view of these results, the reaction conditions were optimised using ligand 1.

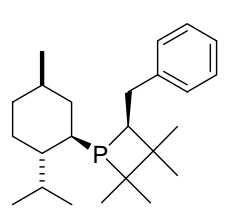

$1 \mathrm{P}(R) \mathrm{C}(\mathrm{S})$<smiles>CC1CC(C)C(P(C2OC(C)CCC2C(C)C)C2OC(C)C(C)(C)C2(C)C)O1</smiles>

$3 \mathrm{P}(R) \mathrm{C}(R)(R, R)$<smiles>CC1CCC(C(C)C)C(P(C2OC(c3ccccc3)C(C)C2(C)C)C2OC(c3ccccc3)C(C)(C)C2(C)C)C1</smiles>

$2 \mathrm{P}(R) \mathrm{C}(R)(R, R)$

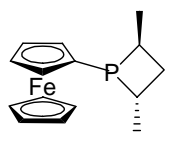

$4(S, S)$

Fig. 2. Chiral phosphetanes used in this study.

In order to first determine the optimum reaction temperature for the $\mathrm{PdCl}_{2} / \mathbf{1} / p$-TsOH system, the $\mathrm{CO}$ pressure was kept constant at 35 bars and the reaction temperature varied from 25 to $70^{\circ} \mathrm{C}$. Under these conditions, the highest selectivity was obtained at $50^{\circ} \mathrm{C}$ with both conversion and the branched to linear products ratio being superior to $99 \%$ and the ee of $10 \%$ (run 5). When the reaction was repeated with a lower concentration of $\mathrm{PdCl}_{2}$ (run 7), the conversion was found to be $48 \%$, but illustrating an increase in catalyst activity (TOF $=2 \mathrm{vs.} 1.03 \mathrm{~h}^{-1}$ ). Rising the CO pressure resulted in the reduction of both conversion and enantioselectivity of the reaction (run 8). Increasing the acidity of the media was found to be beneficial to the activity of this system (run 9, TOF $=3.38 \mathrm{~h}^{-1}$ ).

Experiments were therefore performed using the isolated complex $\operatorname{PdCl}_{2}(3)_{2}$ as the catalyst precursor. The results obtained show that $\mathrm{PdCl}_{2}(3)_{2}$ is a convenient catalyst precursor for this reaction with the desired branched ester produced in higher yield and with higher chemoselectivity (run 10) than the selectivities obtained when the catalyst was prepared in situ (run 3). It is noteworthy that when the concentration of $\mathrm{PdCl}_{2}(3)_{2}$ was lowered to 0.5 mol\% (run 11), the enantioselectivity of the reaction was improved significantly (ee $=29 \%$ ).

Table 1. Methoxycarbonylation of styrene using $\mathrm{PdCl}_{2} /$ phosphetane $/ p-\mathrm{TsOH}$ system ${ }^{\mathrm{a}}$

\begin{tabular}{ccccccccc}
\hline Run $^{\mathrm{a}}$ & Catalyst & Ligand & $\mathrm{P} \mathrm{CO}$ & $\mathrm{T}\left({ }^{\circ} \mathrm{C}\right)$ & $\% \mathrm{C}$ & $\%(\mathrm{~b}+\mathrm{l})$ & $\mathrm{b}: 1$ & \%ee \\
\hline 1 & $\mathrm{PdCl}_{2}$ & $\mathbf{1}$ & 35 & 70 & 97 & $>99$ & $98: 2$ & $12(R)$ \\
2 & $\mathrm{PdCl}_{2}$ & $\mathbf{2}$ & 35 & 70 & 35 & 95 & $96: 4$ & $3(S)$ \\
3 & $\mathrm{PdCl}_{2}$ & $\mathbf{3}$ & 35 & 70 & 19 & 62 & $99: 1$ & 0 \\
4 & $\mathrm{PdCl}_{2}$ & $\mathbf{4}$ & 35 & 70 & 5 & 21 & $99: 1$ & nd \\
5 & $\mathrm{PdCl}_{2}$ & $\mathbf{1}$ & 35 & 50 & $>99$ & $>99$ & $99: 1$ & $10(R)$ \\
6 & $\mathrm{PdCl}_{2}$ & $\mathbf{1}$ & 35 & 25 & $<1$ & - & - & - \\
$7^{\mathrm{c}}$ & $\mathrm{PdCl}_{2}$ & $\mathbf{1}$ & 35 & 50 & 48 & $>99$ & $98: 2$ & $14(R)$ \\
$8^{\mathrm{c}}$ & $\mathrm{PdCl}_{2}$ & $\mathbf{1}$ & 60 & 50 & 37 & 99 & $97: 3$ & $4(R)$ \\
$9^{\mathrm{c}, \mathrm{d}}$ & $\mathrm{PdCl}_{2}$ & $\mathbf{1}$ & 35 & 50 & 81 & 97 & $97: 3$ & $10(R)$ \\
10 & $\mathrm{PdCl}_{2}\left(\mathrm{Ligand}_{2}\right.$ & $\mathbf{3}$ & 35 & 70 & 81 & $96-$ & $96: 4$ & 0 \\
$11^{\mathrm{e}}$ & $\mathrm{PdCl}_{2}\left(\mathrm{Ligand}_{2}\right.$ & $\mathbf{3}$ & 35 & 70 & 26 & 94 & $97: 3$ & $29(R)$ \\
\hline
\end{tabular}

${ }^{a}$ Reaction conditions: 4 mol\% Pd (0.015 mmol), L/Pd = 2, 24h, MeOH:THF (1:1), $0.15 \mathrm{mmol} p$-TsOH.

${ }^{\mathrm{b}}$ Enantiomeric excesses were determined by ${ }^{1} \mathrm{H}$ NMR spectroscopy using $\mathrm{Eu}(\mathrm{hfc})_{3}$ as the chiral shift reagent and by HPLC analysis (Daicel CHIRACEL OJ, hexane/2-propanol = 95/5, $1.5 \mathrm{ml} \mathrm{min}^{-1}$ ). C, conversion; b, branched ester; l, linear ester.

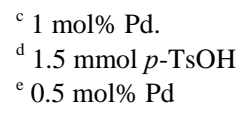

In conclusion, we have demonstrated that monodentate phosphetanes are suitable chiral ligands for the palladium-catalysed asymmetric methoxycarbonylation of styrene. Under mild conditions, the chemo- and regioselectivity of this reaction were found to be excellent, with production of the corresponding branched ester in high yield. The catalytic process takes place with fair stereoselectivity, with ee up to $29 \%$ when the isolated complex $\mathrm{PdCl}_{2}(3)_{2}$ was used as the catalyst precursor. Further investigations on the coordination chemistry of these ligands and the catalytic activity of 
the corresponding palladium complexes are currently on going and will be reported in due course. The tuning of their steric and electronic properties will be investigated in detail in order to optimise the enantioselectivity of the reaction.

\begin{abstract}
Acknowledgements
We are grateful to the Spanish Ministerio de Educación y Ciencia CTQ2004-04412 and EC contract HPRN-CT-2002-00196t for financial support and Generalitat de Catalunya (DURSI) for awarding a research grant to B. Muñoz. We thank Prof. PWNM van Leeuwen, Prof. Kyoko Nozaki
\end{abstract} and Dr. Cyril Goddard for their helpful contributions.

\title{
References
}

1. W. Gerharzt (Ed) Ullmanns Encyclopedia of Industrial Chemistry, Vol. 3 (VCH, Weinheim 1985), p.41.

2. K. Nozaki, I. Ojima in : I. Ojima (Ed), Catalytic Asymmetric Synthesis, second ed., Wiley, New York, 2000. p. 448.

3. (a) S. Oi, M. Nomura, T. Aiko, Y. Inoue, J. Mol. Catal. A 115 (1997) 289. (b) H. Zhou, J. Hou, J. Cheng, S. Lu, H. Fu, H. Wang J. Organomet. Chem. 543 (1997) 227.

4. F. Lagasse, H. Kagan Chem. Pharm. Bull. 48 (2000) 315

5. G. Cometti, G.P. Chiusoli, J. Organomet. Chem. 236 (1982) C31.

6. K. Nozaki, M. Lakshmi-Kantam, T. Horiuchi, H. Takaya, J. Mol. Catal. A 118 (1997) 247.

7. Y. Kawashima, K. Okano, K. Nozaki, T. Hiyama, B. Chem. Soc. Jpn. 77 (2004) 347.

8. I.del Río, N. Ruiz, C. Claver, J. Mol. Cat. A 161 (2000) 39.

9. I. Del Río, C. Claver, P.W.N.M. van Leeuwen, Eur. J.Inorg. Chem. (2001) 2719

10. A. Marinetti, D. Carmichael, Chem. Rev. 102 (2002) 201.

11. A. Marinetti, V. Kruger, F.-X. Buzin. Coord. Chem. Rev., 178-180 (1998) 755.

12. (a) A. Marinetti and J.-P. Genet, C.R. Chimie 6 (2003) 507;

(b) A. Marinetti, F. Labrue, J.-P. Genet, Synlett (1999) 1975.

13. (a) A. Marinetti, L. Ricard, Organometallics, 13 (1994) 3956;

(b) A. Marinetti, V. Kruger, L. Ricard, J. Organomet. Chem., 529 (1997) 465;

(c) T. Imamoto, N. Oohara H. Takahashi, Synthesis (2004) 1353;

(d) A. Marinetti, F. Labrue, B. Pons, L. Ricard, J.-P. Genet, Eur. J. Inorg. Chem., 14 (2003) 2583;

(e) J.-P. Genet, A. Marinetti and V. Ratovelomanana-Vidal, Pure Appl. Chem., 73(2) (2001) 299;

(f) A. Marinetti, S. Jus, J.-P. Genet, Tetrahedron Let., 40 (1999) 8365.

14. (a) A. Marinetti, L. Ricard, Tetrahedron 49 (1993) 10291.

(b) A. Marinetti, S. Jus, F. Labrue, A. Lemarchand, J.-P. Genet, L. Ricard, Synthesis (2001) 2095 
